\title{
Penerapan Model Numbered Heads Together Untuk Meningkatkan Hasil Belajar IPA Peserta Didik Pada Materi Klasifikasi Makhluk Hidup di Kelas VII-D SMP Negeri 9 Manado
}

\author{
Hiskia Koloten ${ }^{1 *}$, Jovialine A. Rungkat ${ }^{2}$ \\ 1,2 Jurusan Pendidikan IPA, FMIPA, Universitas Negeri Manado \\ "e-mail: hiskiakoloten27@gmail.com
}

\begin{abstract}
Abstrak. Penelitian ini bertujuan untuk meningkatkan hasil belajar siswa pada materi klasifikasi makhluk hidup di kelas VII-D SMP Negeri 9 Manado. Penelitian ini dilaksanakan dengan tujuan untuk meningkatkan hasil belajar IPA dengan menggunakan model pembelajaran Numbered Heads Together (NHT). Penelitian ini dilaksanakan dengan 2 siklus. Perangkat pembelajaran yang digunakan yaitu RPP dan lembar observasi. KKM yang ditentukan di sekolah yaitu 70. Pada siklus I materi klasifikasi makhluk hidup, jumlah siswa yang tuntas KKM ada 16 orang dengan persentase klasikal 64\% kemudian dilanjutkan pada siklus II dengan materi klasifikasi kunci dikotom dan kunci determinasi, jumlah siswa yang tuntas 24 orang dengan persentase klasikal 96\%. Disimpulkan bahwa terjadi peningkatan hasil belajar IPA pada materi klasifikasi makhluk hidup kelas VII-D SMP Negeri 9 Manado.
\end{abstract}

Kata kunci: numbered heads together, hasil belajar, klasifikasi makhluk hidup

\begin{abstract}
This study aims to improve student learning outcomes in classification of living things in class VII-D of SMP Negeri 9 Manado. This research was conducted with the aim of improving science learning outcomes using the Numbered Heads Together (NHT) learning model. This research was conducted in 2 cycles. The learning tools used were lesson plans and observation sheets. The KKM determined in the school is 70 . In the first cycle the material for the classification of living things, there are 16 students who have completed the KKM with a classical percentage of $64 \%$ then continued in the second cycle with the dichotom key classification material and the key to determining the number of students who have completed 24 people with the classical percentage $96 \%$. It was concluded that there was an increase in science learning outcomes in the classification material for class VII-D of SMP Negeri 9 Manado

Keywords: numbered heads together, learning outcomes, classification of living things
\end{abstract}

Diterima 10 November 2020 | Disetujui 23 Desember 2020 | Diterbitkan 31 Desember 2020

\section{PENDAHULUAN}

Berbagai upaya telah dilakukan untuk meningkatkan mutu pendidikan di sekolah, antar lain dengan perbaikan mutu pembelajaran. Pembelajaran di sekolah merupakan serangkaian kegiatan yang secara sadar telah terencana. Dengan adanya perencanaan yang baik akan mendukung keberhasilan pengajaran. Usaha perencanaan pengajaran diupayakan agar peserta didik memiliki kemampuan maksimal dan meningkatkan motivasi, tantangan dan kepuasan sehinga mampu memenuhi harapan baik oleh guru sebagai pembawa materi maupun peserta didik sebagai penggarap ilmu pengetahuan (Astute 2012).

Belajar dapat didefinisikan sebagai suatu proses dimana suatu organisme berubah perilakunya sebagai akibat pengalaman. Belajar dan mengajar merupakan dua konsep yang tidak dapat dipisahkan satu sama lain. Dua konsep 
ini menjadi terpadu dalam satu kegiatan dimana terjadi interaksi antara guru dengan siswa, serta siswa dengan siswa pada saat pembelajaran berlangsung (Susanto, 2013).

Guru sebagai salah satu komponen dalam proses pembelajaran merupakan pemegang peran yang sangat penting. Sebagai pengatur sekaligus pelaku dalam proses pembelajaran, gurulah yang mengarahkan bagaimana proses pembelajaran itu dilaksanakan. Karena itu guru harus dapat membuat suatu pengajaran menjadi lebih efektif juga menarik menggunakan model pembelajaran yang menyenangkan sehingga bahan pelajaran yang disampaikan akan membuat siswa merasa senang dan merasa perlu untuk mempelajari bahan pelajaran tersebut.

Pembelajaran kooperatif merupakan strategi pembelajaran yang mengutamakan adanya kerjasama antar siswa dalam kelompok untuk mencapai tujuan pembelajaran. Para siswa dibagi ke dalam kelompok-kelompok kecil dan diarahkan untuk mempelajari materi pelajaran yang telah ditentukan. Tujuan dibentuknya kelompok kooperatif adalah untuk memberikan kesempatan kepada siswa agar dapat terlibat secara aktif dalam proses berpikir dan dalam kegiatan-kegiatan belajar. Dalam hal ini sebagian besar aktifitas pembelajaran berpusat. (Sumampouw, 2012)

Pembelajaran kooperatif tipe NHT merupakan salah satu tipe pembelajaran kooperatif yang menekankan pada struktur khusus yang dirancang untuk mempengaruhi pola interaksi siswa dan memiliki tujuan untuk meningkatkan penguasaan akademik. (Herdian, 2009)

Hasil belajar adalah prestasi belajar siswa secara keseluruhan yang menjadi indikator kompetensi dan derajat perubahan prilaku yang bersangkutan. Kompetensi yang harus dikuasai siswa perlu dinyatakan sedemikian rupa agar dapat dinilai sebagai wujud hasil belajar siswa yang mengacu pada pengalaman langsung (Mulyasa, 2008). Belajar juga merupakan suatu proses perubahan yaitu perubahan tingkah laku sebagai hasil dari interaksi dengan lingkungannya dalam memenuhi kebutuhan hidupnya (Slameto (2010). Lebih lanjut, belajar juga disebut sebagai perubahan yang terjadi di dalam diri seseorang setelah melakukan aktivitas tertentu (Fathurrohman \& Sobry, 2009).

Berdasarkan hasil observasi terhadap guru di SMP Negeri 9 Manado kelas VII-D, bahwa hasil belajar IPA masih rendah, hal ini disebabkan siswa belum secara aktif terlibat dalam proses pembelajaran atau terlalu banyak bermain dan mengganggu teman, guru belum menerapkan model pembelajaran numbered head together yang dapat membuat siswa aktif dalam pembelajaran dan secara aktif juga menunjukan pola interaksi antara siswa. Hal ini juga dapat dilihat dari nilai hasil belajar untuk materi klasifikasi makhluk hidup, dari 25 peserta didik, hanya 11 peserta didik yang memperoleh nilai 75-85 artinya hanya mencapai $44 \%$ dan yang mendapat nilai $45-74$ ada 14 peserta didik yang artinya mencapai $56 \%$, sehingga hasil belajar rendah.

Oleh karena itu, peneliti melakukan penelitian tindakan kelas ini untuk meningkatkan hasil belajar IPA siswa materi klasifikasi makhluk hidup di kelas VII-D SMP Negeri 9 Manado.

\section{METODE PENELITIAN}

Penelitian ini merupakan Penelitian Tindakan Kelas (PTK) yang dilaksanakan pada pada semester genap tahun ajaran 2018/2019. Subjek dalam penelitian ini adalah siswa kelas VII-D di SMP Negeri 9 Manado yang berjumlah 25 orang siswa, yang terdiri dari 14 orang laki-laki dan 11 orang perempuan.

Sumber data dalam penelitian ini adalah personil penelitian yang terdiri dari peserta didik dan guru. Jenis data dalam penelitian ini adalah data kuantitatif. Data kuantitatif diperoleh dari hasil pekerjaan siswa dalam mengerjakan soal tes siklus 1 dan siklus 2. Cara pengambilan data yaitu data hasil belajar diambil dengan memberikan tes, hasil wawancara dengan guru dan murid, dan data tentang keadaan pembelajaran berlangsung menggunakan materi 
klasifikasi makhluk hidup yang diambil dengan menggunakan lembar observasi.

Indikator kerja yang digunakan dalam penelitian tindakan kelas ini adalah nilai Kriteria Ketuntasan Minimal (KKM) sebesar 70 yang mengacu pada Kurikulum 2013 dimana hasil belajar dikatakan tuntas apabila ketuntasan klasikal 80\% dari seluruh siswa kelas VIID di SMP Negeri 9 Manado.

Instrument penelitian yang digunakan adalah Rencana Pelaksanaan Pembelajaran (RPP), Lembar Kerja Siswa (LKS), dan lembar observasi. Data yang diperoleh dari hasil penelitian ini dihitung dengan cara menghitung persentase ketuntasan belajar peserta didik.

Penelitian Tindakan Kelas (PTK) dilaksanakan 2 siklus sesuai ketercapaian tujuan pembelajaran. Prosedur penelitian yaitu:

1. Perencanaan, pada tahap ini kegiatan yang dilakukan yaitu menyusun silabus, RPP, lembar kerja siswa, lembar observasi siswa dan guru dan menyiapkan alat evaluasi berupa soal. Pelaksanaan tindakan penelitian ini berdasarkan RPP dalam kegiatan pembelajaran dengan menggunakan model NHT materi klasifikasi makhluk hidup.

2. Tindakan, pada tahap ini, tindakan dilaksanakan dilingkungan sekitar sekolah SMP Negeri 9 Manado, sesuai dengan RPP dan menggunakan model NHT materi klasifikasi makhluk hidup.

3. Observasi, kegiatan observasi atau pengamatan terhadap seluruh kegiatan siswa selama proses pembelajaran berlangsung dengan lembar observasi yang telah dibuat oleh peneliti. Hal yang harus diamati oleh peneliti adalah aktivitas siswa selama berlangsungnya proses pembelajaran, dan proses pembelajaran dapat terlaksana sesuai dengan rencana pelaksanaan pembelajaran. Kegiatan pemantauan dilakukan oleh guru mata pelajaran IPA SMP Negeri 9 Manado.

4. Refleksi, peneliti akan melakukan refleksi terhadap proses dan hasil tindakan yang dilakukan. Jika tindakan yang dilakukan sudah mencapai keberhasilan maka peneliti tidak melanjutkan pada siklus berikutnya.

\section{HASIL DAN PEMBAHASAN}

Hasil penelitian tindakan kelas yang dilakukan pada siswa kelas VII-D SMP Negeri 9 Manado yang berjumlah 25 orang, dapat dilihat pada Tabel 1.

Tabel 1. Persentase keterlaksanaan proses pembelajaran

\begin{tabular}{ll}
\hline Siklus & Persentase \\
\hline Siklus I & $64 \%$ \\
Siklus II & $96 \%$ \\
Peningkatan & $32 \%$ \\
\hline
\end{tabular}

Penelitian pada siklus I, hasil belajar siswa mendapatkan hasil yang kurang memuaskan atau hasil belajar tidak mengalami peningkatan dimana dari 25 siswa hanya 16 siswa yang mencapai KKM (standar KKM 70) sedangkan 9 siswa lainnya belum mencapai KKM sehingga pencapaian klasikal hanya sebesar $64 \%$.

Belum tercapainya proses pembelajaran dengan model NHT membuat peneliti harus melanjutkan pada tahap berikut yaitu siklus II dengan memperhatikan hal-hal pada siklus I yaitu dengan melakukan beberapa perbaikan diantaranya dalam proses pembelajaran dikelas guru harus menciptakan suasana belajar yang menyenangkan, menyampaikan materi dengan volume suara yang lebih diperkeras lagi agar seluruh siswa dapat mendengarkan penyampaian materi dengan jelas dan dapat membuat siswa aktif dalam proses pembelajaran, guru harus lebih memperhatikan pengelolaan kelas, memberikan motivasi, begitu juga dengan jalannya diskusi antara kelompok yang masih kurang kerjasama dalam pengamatan atau dalam mengisi LKS dan siswa kurang semangat melakukan pengamatan.

Peneliti lebih melakukan pendekatan kepada siswa agar dapat dengan mudah memahami dan mengerti dengan pembelajaran yang sudah diberikan dan dapat membentuk perilaku siswa dimana ada kemauan untuk belajar 
dan lebih bersemangat dalam menerima pembelajaran sehingga hasil belajar bisa meningkat.

Penelitian pada siklus II hasil belajar meningkat dimana dari 25 siswa, 24 siswa yang mencapai KKM (standar KKM 70) sedangkan 1 siswa lainnya belum mencapai KKM sehingga pencapaian klasikal mencapai 96\%. Pada siklus II ini ada 1 siswa yang tidak mencapai KKM dikarenakan kurang memperhatikan selama proses pembelajaran berlangsung, sehingga tidak memahami materi yang telah diberikan guru. Kurangnya keaktifan dalam kelas. Seseorang dikatakan telah belajar apabila telah mengalami perubahan perilaku sesuai dengan apa yang dipelajari serta hasil belajar yang memuaskan.

Hasil

memperlihatkan peningkatan hasil belajar siswa yang mengalami peningkatan klasikal sebesar 32\%. Dari hasil belajar yang dicapai sangat bagus sehingga kedepannya bisa dipertahankan dan lebih ditingkatkan.

Setiap proses belajar mengajar selalu menghasilkan hasil belajar. Masalah yang dihadapi adalah sampai di tingkat mana prestasi (hasil) belajar yang telah dicapai (Djamarah \& Aswan, 2010). Hasil belajar merupakan perubahan perilaku yang diperoleh siswa setelah mengalami aktivitas belajar. Hasil belajar dapat terlihat oleh tingkah laku siswa setelah melakukan kegiatan belajar mengajar (Rusman, 2011).

Hal ini senada dengan penelitian yang dilakukan oleh Sari (2012), yang menyatakan bahwa untuk belajar diperlukan motivasi, semakin tinggi motivasi belajar siswa akan semakin tinggi tingkat keberhasilan. Selain itu, menurut Ibrahim, dkk (2020), model pembelajaran kooperatif dapat meningkatkan interaksi siswa serta dapat meningkatkan motivasi siswa untuk aktif dalam proses pembelajaran.

\section{KESIMPULAN}

Berdasarkan hasil penelitian yang telah dilakukan, dapat disimpulkan bahwa model pembelajaran numbered heads together dapat meningkatkan hasil belajar IPA siswa kelas VII-D SMP Negeri 9 Manado.

\section{DAFTAR PUSTAKA}

Astute. (2012). Upaya Peningkatan Aktivitas dan Hasil Belajar Siswa Mata Pelajaran Kooperatif IPA Melalui Metode NHT Pada Siswa Kelas V SDN 5 Jatimulyo Kec. Jatiagung Kab. Lampung Selatan. Skripsi.

Djamarah, S. B. \& Aswan, Z. (2010). Strategi Belajar Mengajar. Jakarta: Rineka Cipta.

Fathurrohman P. \& Sobry S. (2009). Srategi Belajar Mengajar: Strategi Mewujudkan Pembelajaran Bermakna Melalui Penanaman Konsep Umum Dan Konsep Islami, Bandung: PT Refika Aditama.

Herdian. (2009). Model Pembelajaran NHT (Numbered Head Together). Diakses pada 30 November 2020, dari http://www.eazhull.org.uk/nlc/numbere d heads.htm.

Ibrahim, M., dkk. (2000). Pembelajaran Kooperatif. Surabaya: Surabaya University Press.

Mulyasa, E. (2008). Menciptakan Pembelajaran Kreatif dan Menyenangkan. Bandung: PT. Remaja Rosdakarya.

Rusman. (2011).

Model-Model Pembelajaran Mengembangkan Profesionalisme Guru. Jakarta: PT. Rajagrafindo Persada.

Susanto. (2013). Belajar dan FaktorFaktor yang Mempengaruhinya. Jakarta: PT Rineka Cipta.

Sumampouw, H. (2012). Pembelajaran Genetika Dengan Strategi RQA Berbasis Keterampilan Metakognitif. Yogyakarta: Titah Surga.

Sari, K. D. P. (2012). Peningkatan Kemampuan Berpikir Tingkat Tinggi Dan Hasil Belajar Melalui Penerapan Pemberdayaan Berpikir Melalui Pertanyaan (PBMP) Dalam Metode Eksperimen Pada Siswa Kelas X SMA NEGERI 1 Maron Kabupaten Probolinggo. Disertasi. Malang: University of Muhammadiyah Malang. 
Slameto. (2010). Belajar dan Faktor-

Faktor yang Mempengaruhinya.

Jakarta: PT Rineka Cipta. 